\title{
Swiss Defence Industry in the Global Arms Trade - Successes and Challenges
}

\section{Donatas Palavenis}

ORCID iD: 0000-0003-0908-7512

The General Jonas Žemaitis Military Academy of Lithuania

Šilo str. 5A, LT-10322 Vilnius, Lithuania.

$+37052103582$

donatas.palavenis@mil.It

Author Biography. Major Donatas Palavenis is Lithuanian army officer currently serving in the Headquarters of Multinational Corps North East, and at the same time, a $\mathrm{PhD}$ candidate at the General Jonas Žemaitis Military Academy of Lithuania in the Research Project Support Section. His research interests are: defence industry, defence policy, political economy, defence economics, and arms procurement.

Abstract. When we talk about the Defence Industry (DI), arms transfers, and military expenditures we mostly refer to data accumulated by the Stockholm International Peace Research Institute (SIPRI). In the SIPRI Top 20 list of largest exporters of major arms for 2019, small states hold consecutive positions: Israel takes 8th place, Switzerland is 13th, and Sweden, Norway, and Belarus place 15th, 17th, and 20th respectively. The author analyses the Swiss DI case due to several reasons; its place in SIPRI Top, its sharp rise of Swiss arms exports in the recent year, its Swiss neutrality strategy, the country's multilingual society, and its all-government approach to the arms industry, though still contributing to the limited scholarly studies on contemporary Swiss DI. This paper aims to explore Swiss DI and its strategies, to identify the country's defence and security policy influence towards DI, and to discuss the Swiss DI stance and future perspectives in the context of the global arms trade. At the same time, this paper also highlights Swiss DI successes and failures that could be of significant use to other small states aiming to develop or enhance their relevant DIs.

Keywords. Switzerland, defence industry, defence policy, the Federal Office for Defence Procurement, RUAG, arms export.

\section{Introduction}

When we talk about indigenous defence industry (DI), arms transfers, and military expenditures, we mostly refer to data accumulated by the Stockholm International Peace Research Institute (SIPRI). In this work, SIPRI data was used as a reference to indicate relative players in the DI context. For better context, this paper addresses information from two SIPRI databases: the list of Top 20 largest exporters of major arms (SIPRI, 2020d), and the list of Top 100 arms-producing and military services companies in the world (SIPRI, 2019). As the information primarily looks into the ways to boost DIs for small states, the analysis was narrowed down accordingly (Kurečić, Kozina, \& Kokotović, 2017). In the SIPRI Top 20 list of 
largest exporters of major arms, one could see only Israel (8th place), Switzerland (13), Sweden (15), Norway (17), and Belarus (20) representing small states. These five countries together compose a 5.2 percent share of global arms exports. Regarding the SIPRI Top 100 armsproducing and military services companies in the world, Singapore joins these five countries as one of the small countries ranked high on the list (Table 1).

Table 1. Companies from small countries in the SIPRI Top 100 arms-producing and military services companies in the world list(SIPRI, 2019)

\begin{tabular}{|c|c|c|}
\hline Place & Company name & Country \\
\hline 28 & Elbit Systems & Israel \\
\hline 30 & Saab & Sweden \\
\hline 39 & Israel Aerospace Industries & Israel \\
\hline 44 & Rafael & Israel \\
\hline 61 & ST Engineering & Singapore \\
\hline 94 & RUAG & Switzerland \\
\hline
\end{tabular}

Also worth mentioning, Singapore hosts the established subsidiaries and/or manufacturing capabilities of 11 companies from other countries (SIPRI, 2020a).

Each of the previously mentioned countries present an interesting significance, but the author selected Switzerland's DI significance for further analysis based on the following reasons: Switzerland's place in the SIPRI Top 20 and Top 100 lists, the sharp rise of Swiss arms exports in the most recent year, Switzerland's neutrality strategy, the country's multilingual society, its all-government support for the arms industry, and finally due to its limited scholarly studies available on contemporary developments of Swiss DI.

This paper aims to explore Swiss DI and its strategies, to identify the country's defence and security policy influence towards DI, and to discuss the Swiss DI stance and future perspectives in the context of the global arms trade. It highlights the successes and failures of Swiss DI that could be more logically used by other small states to establish or enhance their DIs. The paper also seeks to contribute to the analysis on Swiss DI previously conducted by Stefan Markowski in 1998 as it covers in detail the developments of Swiss DI within the last two decades and discusses other perspectives of Swiss DI that were not taken into consideration previously by other scholars.

The developments of Swiss defence, armaments policy, and the DI field were not extensively analysed by academia. Markowski (1998) analysed the Swiss approach to defence procurements in which he came up with the following findings: procurements are assessed in the context of long term cost effects; domestic DI is encouraged to participate in national procurements; arms exports are supported by the government; most of the contracts are pricefixed with an agreed upon rate of return of capital investments; and some local defence market 
niches remain protected. Markowski and Robert Wylie noted that Switzerland as a highly industrialised European country which could export their defence products despite a limited home base, but they would find it to be harder to do in the future as weapon systems become more system-based and integrated into cross-platform systems. Therefore, supplies from independent suppliers would likely not be accepted. They foresaw that specialized Swiss manufactures would become second tier suppliers to larger systems (Markowski \& Wylie, 2007). Heiko Borchert and René Eggenberger analysed developments in the European Security Defence Policy, discussed the Swiss' role in initiatives towards specialization and pooling of resources, while also considering the impact on Switzerland's defence security policy and military posture if the country were to join the EU. Borchert and Eggenberger focused on the question of where to best to incorporate Swiss armament procurement policies and how to modernize Swiss security and military policy planning processes. They concluded that Switzerland has to direct its own DI on strategically important sectors, team up for international armaments projects, have the Swiss Armed Forces (AF) establish better means of communication, and to make the Swiss Parliament and the public more aware of the need to replace aging equipment (Borchert \& Eggenberger, 2003). In his latest study, Keith Harley (2019) reviewed the Swiss DI status with his most current focus on Swiss DI mergers and acquisitions and on defining future prospects for domestic DI.

Internet search engine, Google Scholar, was used to select scientific sources for case study and literature analysis using key words 'Defence industry' and 'Switzerland' to find related information going back to 1998. From the results, the first 20 relevant articles were used for analyses. Additionally, significant data was compiled from several indigenous websites and also the websites of the Swiss Department of Defence, Civil Protection and Sport (DDPS), the Federal Office for Defence Procurement (FODP), the European Defence Agency (EDA), NATO, SIPRI, the State Secretariat for Economic Affairs, and the Swiss AF. Other data was collected from international and local news agencies like Armada International, Swissinfo, and the Voz. The compilation of data was analysed and interpreted using context, quantitative, and qualitative comparative analysis.

\section{The Department of Defence, Civil Protection and Sport}

In most countries, the Department of Defence is a standalone structure in the governmental hierarchy. In regards to Switzerland, they are unique in that regard as DDPS has to execute civil protection and sport functions. DDPS consists of the General Secretariat, the 
Office of the AF Attorney General, the Federal Intelligence Service (FIS), the Federal Office for Sport, the Federal Office for Civil Protection, the Federal Office of Topography, the Swiss AF, and the FODP (figure 1) (DDPS, 2021f).

The General Secretariat supports the head of DDPS with managing the department. It consists of five administrative units that take care of planning and coordination at the department level (DDPS, 2021d).

The Office of the AF Attorney General is responsible for the military tribunal system and initiates criminal proceedings and supervises decision implementation. The military tribunal system consists of three sections, the Military tribunals, the Military court of appeal, and the Military Supreme Court (DDPS, 2021e).

The FIS is responsible for preventing espionage, terrorism, extremism, cyber attacks against critical infrastructure, and the proliferation of weapons of mass destruction. FIS provides many products for the Federal Council and the military command, while also assisting federal law enforcement authorities and helping the cantons to maintain inner security (DDPS, 2020b).

The Federal Office for Sport aims to promote sports and exercise amongst all age groups and at all levels of ability amongst athletes across Switzerland. The Federal Office consists of five divisions that enable a variety of services for elite, professional, and amateur level athletes, develops knowledge and practice skills required to teach both sports amateurs and professionals, and plays a leading role in developing sports infrastructure (DDPS, 2021b).

The Federal Office for Civil Protection is responsible for civil protection at the federal level. It consists of 340 employees that form six organisational units obliged to inform the public about hazards by alerting the population in the event of an emergency, manage the emergency situation, and deploy five other partner organizations to deal with the emergency physically (DDPS, 2021a).

The Federal Office of Topography employs 350 specialists, some of which serve in a geo-information centre, some conduct surveys and document landscapes, both above and below ground level, some coordinate geo information and geology activities, some run the Institute for Military Geography, and some supervise the official cadastral surveying system (DDPS, 2021c).

The Swiss AF is led by the Chief of the AF. The AF consists of several departments; AF Staff, the Joint Operations Command, the AF Logistics Organization, the AF Command Support Organization, and the Training and Education Command. 


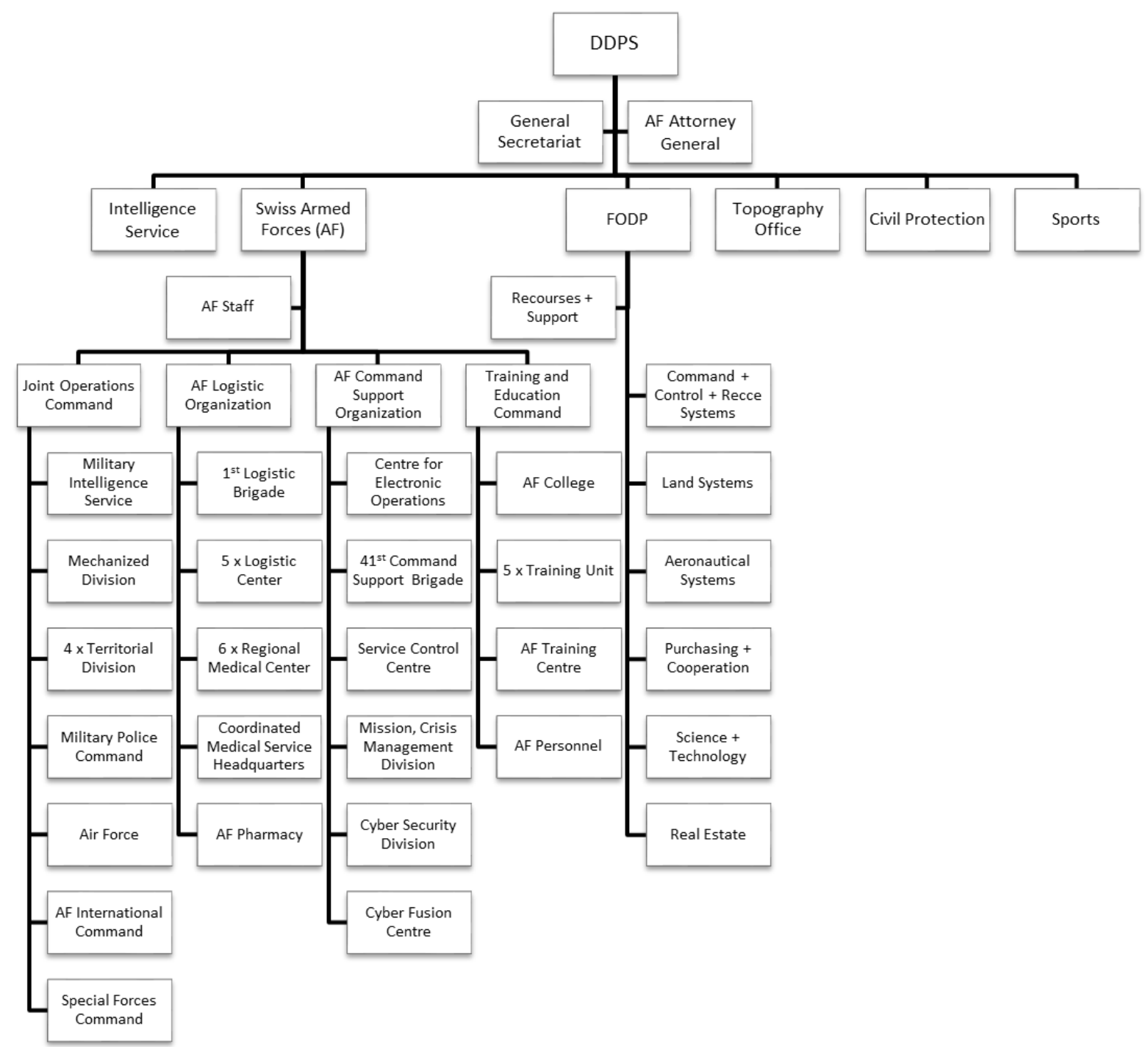

Figure 1. DDPS and subordinate elements' structure (FODP, 2020d; Swiss AF, 2020)

The FODP is responsible for the development, evaluation, procurement and disposal of equipment and systems of the Swiss AF, and the management of DDPS real estate. At the same time, FODP serves as a fourth federal procurement competence centre within the governmental procurement system. FODP employs approximately 900 employees, signs more than 16,000 orders/contracts per year, and runs 24,000 hectares of property and 7,500 objects. FODP operates based on a certified management system (ISO 9001, 14001) and uses the SAP accounting system to ensure transparent cost management. FODP consists of four structural elements: Command, Control and Reconnaissance systems, Aeronautical systems, Land systems, and Purchasing and Cooperation systems are all together responsible for active participation in the customers' planning process, procurement, management, and disposal. Another FODP structural element, Science and technology $(\mathrm{S}+\mathrm{T})$ consists of six specialized 
departments: Explosives and Ammunition Surveillance, Sensor Technology, Networks and Protection, Test Centre, Research Management, Operations Research, and Cyber Security and Data Science. S+T tests and evaluates current and future systems of the Swiss AF and other end users in terms of operational capability, functionality, efficiency, and security requirements. S+T's budget for 2020 was 28.9 million CHF wherein there is a planned increase of up to 32.2 million CHF for 2021. The last structural element of FODP is Real estate, which is responsible for planning, management of objects, the realisation of new developments and reconstruction, and for the sale and liquidation of infrastructure that isn't used (FODP, 2020d).

In summary, Switzerland has a unique structure of Department of Defence whose functions encompass spheres of sport and civil protection. DDPS has a centralized procurement element - FODP, which cares not only about Swiss AF, but also supports other DDPS departments. FODP employs about 900 specialists and has four specialized units for different procurement programs, i.e. land systems, which have its own S+T element with an annual 32.2 million CHF budget for 2021.

\section{Swiss Armed Forces}

In 2020, the Swiss AF was comprised of 9,333 professionals and 143,372 personnel on active duty. A 21-week conscription in the Swiss AF remains mandatory. Defence spending for the Swiss AF (figure 2) has slightly fluctuated over the last two decades.

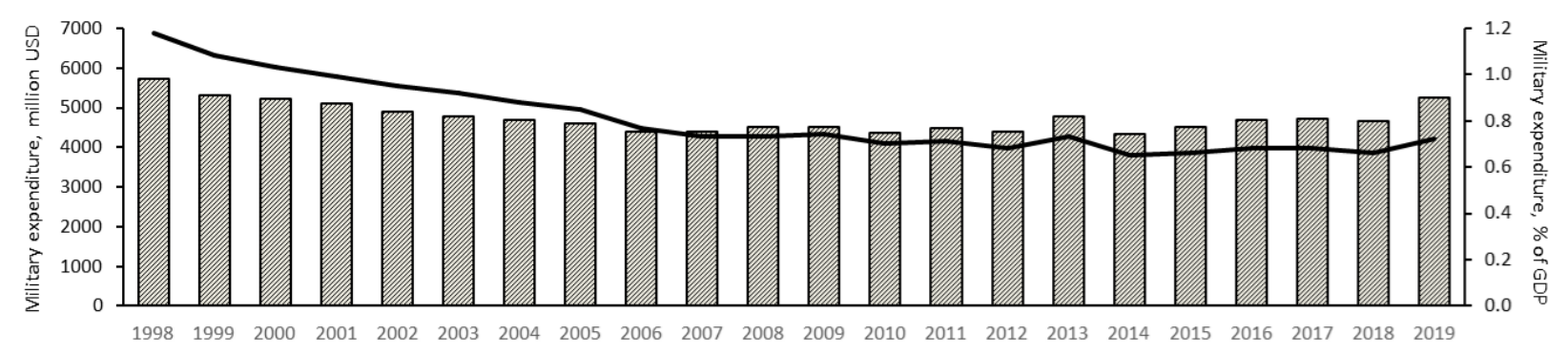

Figure 2. Swiss defence expenditure 1998-2019 (SIPRI, 2020c; The World Bank, 2021)

Keith Hartley noted that the reduction in defence spending was a simple indicator of the peace dividend in Switzerland (Hartley, 2019).

The biggest elements of Swiss AF are land and air forces which are subordinate to the Joint Operations Command (figure 1). The main equipment of land forces consist of tank 87 Leopard WE, armoured personnel carriers type M 113, wheeled infantry fighting vehicle Piranha, reconnaissance vehicles 93, 93/97, 97/06, self-propelled howitzers M 109 KAWEST WE, and heavily armoured 6x6 troop carrier GMTF Duro IIIP. The Swiss AF possess fighters 
F / A-18 C / D Hornet and F-5 E / F Tiger; helicopters Great Puma, Cougar, and EC635; utility aircrafts PC-6 Turbo Porter and PC-9; and trainer PC-21. The AF also possess short-medium range air defence systems Oerlikon, Stinger, and Rapier (figure 3) (DDPS, 2020a).
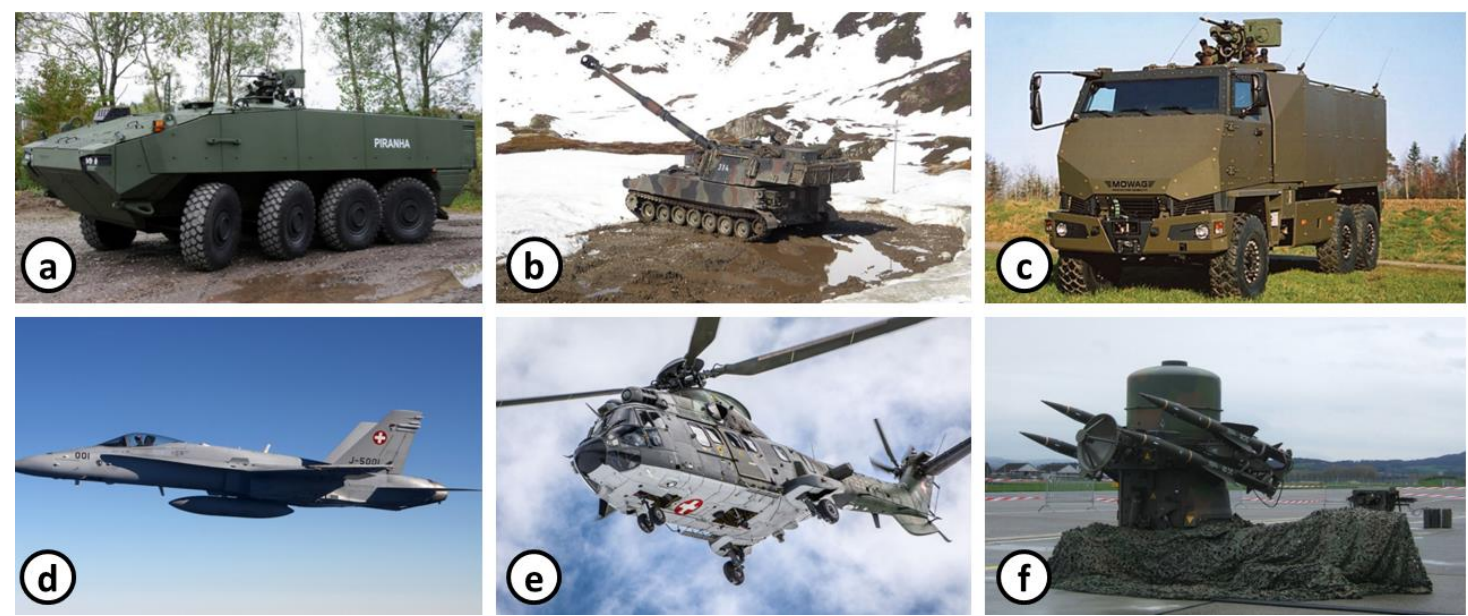

Figure 3. Main equipment of Swiss AF: Piranha (a), M 109 KAWEST WE (b), GMTF Duro IIIP (c), F / A-18 C

/ D Hornet (d), Cougar (e), Rapier (f) (pictures from Wikimedia Commons, military-today.com, militarywiki.com)

In summary, the Swiss AF is comprised of up to 10,000 professional soldiers with an active conscription system and vast reservist system. Swiss land and air forces are also well equipped with some locally manufactured upgraded major arms systems. Defence spending is stable averaging 0.8 percent GDP in the most recent decade.

\section{Swiss participation in other organizations}

As Switzerland is committed to permanent and armed neutrality, it has no intent to become a NATO member. However, even as a non-member, Switzerland is still engaged in some of the cooperation areas with NATO that are specified in the Individual Partnership and Cooperation program. Since 1990, Switzerland is an active player in the NATO Science for peace and security program where it leads several cooperation areas on advanced technology, counter-terrorism, and cyber defence. In 1996, Switzerland became a member of NATO's Partnership for Peace (PfP) programme. The logic to join the PfP programme was based on the programme's coherence with the Swiss neutrality, allowing Switzerland the ability to make a decision with regard to each individual participation event. In 1997, Switzerland also became a member of the Euro-Atlantic Partnership Council (EAPC), which provides the overall political framework for NATO's cooperation with partner countries in the Euro-Atlantic area. The venue is also used for bilateral relationships between individual PfP countries and NATO. As a 
member of PfP and EAPC, Switzerland participates in a Partnership action plan focused on defence institution building initiatives during the activities of the Euro-Atlantic Disaster response coordination centre. Switzerland contributes to NATO Trust Fund projects, such as management of munitions stockpiling and the destruction of mines, arms, and ammunition in Albania, Serbia and Montenegro, Azerbaijan, Kazakhstan, Georgia, Ukraine and Jordan. Switzerland has also instituted a number of military and civilian training facilities available for PfP training activities. Switzerland also contributes its expertise in the fields of humanitarian missions, international humanitarian law, human rights and civil-military cooperation, search and rescue training, civil emergency planning, security policy, arms control and disarmament, and transparency and democratic control of AF. Swiss military units and civilians participate in international operations under the mandate of the UN or Organization for Security and Cooperation in Europe. While deployed in international operations, Swiss troops are not allowed to participate in combat or peace enforcement operations. So far, Switzerland has supported NATO-led operations in the Balkans since 1999 and in Afghanistan from 2004-2007. In 2019, Switzerland became a member of the NATO Cooperative cyber defence centre of excellence in Tallinn, Estonia. This membership initiative would provide Swiss representatives access to the knowledge, information, research and training activities, and would help to implement the national strategy to protect Switzerland against cyber risks (NATO, 2018; Swissinfo.ch, 2019).

The EDA, which is responsible for facilitating defence cooperation in the EU, signed into an Administrative arrangement with Switzerland in 2012 allowing Switzerland the ability to participate in the EDA's projects and programmes (EDA, 2020). The arrangement enables Switzerland to detect EU armaments policy developments, have wider access to R\&D, and to procure and conduct maintenance of armaments. Since the agreement is not legally binding, Switzerland can decide what information it would like to share, and in which activities it intends to participate in. Swiss defence companies and research institutes' interests in EDA's projects are limited to expert participation in various workshop topics, such as hypervelocity systems and high-powered electromagnetic munitions. So far, there has been only one combined study within the EDA framework conducted on the 3D positioning system which was done by Graz University of Technology and the Swedish Defence Research Agency in 2011 (EDA, 2012).

To be more precise, as Switzerland is committed to neutrality, the extent of its participation in international defence organizations is limited. Nevertheless, the Swiss government is looking for opportunities to engage in multiple activities without being legally restricted which allows the AF and DI to gain needed experience and knowledge. NATO, the 
EU, and the EDA are organizations which are attracting Swiss interest for further cooperation in the defence sphere.

\section{Swiss armaments strategy}

Switzerland is no longer involved in the complete development and production of large defence systems, regardless of the fact that the Swiss industrial structure provides a basis for self-reliant defence efforts, especially when it comes to the development of weapon platforms. Switzerland is in no position to force other countries to buy Swiss products and can only sell their products abroad if they are competitive based on cost and quality. Switzerland has a long tradition of supporting small firms by imposing entry restrictions to larger companies allowing smaller businesses to survive (Markowski, 1998).

The Swiss federal government has the following mechanisms to support their domestic security-relevant technological and industrial base (STIB) and boost the competitiveness of Swiss research facilities and defence companies: domestic procurement, offset, international cooperation, applied research, promotion of innovation, exchange of information with industry, and an export control policy. Switzerland, like countries of a similar size, is dependent on imports for armament. As civilian innovations influence technological developments in the defence sector, systems become more reluctant on the manufacturers which pose greater security risks, such as unexpected external controls or external system monitoring (Swiss Federal Council, 2018). However, when all goes well, the overall effort provides great opportunities.

The DDPS armaments strategy is guided by the Federal Council's principles for the armaments policy, which references the needs of the Swiss AF, as well as the support necessary to maintain and build indigenous DI capacity. The Federal Council highlights the need for timely supply and requirements for the processes based on the economic principles which are accomplished in a transparent manner. FODP is responsible for the implementation of the Armament strategy within DDPS (FODP, 2020a; Swiss Federal Council, 2018).

Armament procurement is conducted while ensuring required competition among suppliers and seeking an efficient and economical outcome. It is expected that the competition among suppliers would drive innovation and ensure an optimal cost-to-benefit ratio. It is also desired that procured goods and processes for services would be fully developed, custom made, and interoperable. Foreign security interests are consistently followed in order to strengthen STIB of Switzerland. In this way, competition and/or economic efficiency criteria become less 
relevant. The use of offsets in arms procurement is also not restrictive in Switzerland. It is recognized that the close cooperation among the $\mathrm{AF}$, the administration, the research institutions, the DI, and the security policy relevant partners in Switzerland and abroad are the key elements for modern, innovative, and effective STIB (FODP, 2020a).

During the procurement process, the FODP must ensure that: the contracts without security considerations should be publicly advertised and awarded in open competition; the contracts with security considerations are awarded after direct or invitation tendering with domestic companies; RUAG MRO Switzerland should be considered from the beginning; procurement of goods and systems with short life cycle and/or fast developing technologies must be avoided; the cost should be estimated throughout the entire life cycle of goods and systems; whenever possible, procurements must be accumulated to achieve economies of scale; and in a monopoly situation, transparency for pricing must be introduced (FODP, 2020a).

Maintenance work for armaments and defence systems belonging to the AF would be principally awarded to RUAG MRO Switzerland or other companies from STIB because RUAG MRO Switzerland is providing most of the services needed for the AF. In the future, RUAG MRO Switzerland would gain more influence as the AF's material competence centre will be integrated into it, with the provision being that equipment manufacturers who have their own maintenance and support capabilities and are based in Switzerland (FODP, 2020a). RUAG MRO Switzerland would conduct maintenance and further development and adaptations of systems. This privileged position of RUAG MRO Switzerland with the AF restricts its access to international markets, and at the same time limits the economic survival of this company which makes it rely only on AF allocations (FODP, 2020a).

Swiss Armament Strategy foresaw that domestic procurement would enable and strengthen STIB in many aspects 'as well as the technological competencies and industrial key capabilities relevant for AF.' As priority during armament procurement is given to domestic companies, the partnership between AF/FODP and key industrial partners is essential to ensure supplies are available for all contingencies. Partnerships with domestic companies can be established in the form of 'joint research projects, partnership-based development of components, or entire systems.' Partnership extent is initially defined during the military planning phase, and later contractually agreed upon in the Service Level Agreements. To enable processes, regular dialogue is established between players (FODP, 2020a).

Switzerland protects and supports developments of its own STIB, key scientific, technical competencies, and key capabilities of indigenous DI. Therefore, DDPS is in charge to 
periodically define the economic sectors that form the potential core set of STIB. DDPS identified information, communication, and sensor technologies as security-relevant core technologies in 2020. Development, integration, operation, and maintenance capabilities of critical security-relevant deployment systems were identified as key industrial capabilities. Universities, research institutes, and companies contribute to the development of the competencies in the identified areas. Participation in international research and development $(\mathrm{R} \& \mathrm{D})$ programmes enables robust contribution to the developments of security-relevant core technologies (FODP, 2020a).

DDPS is interested in a defence market with multiple suppliers as it creates competitiveness leading to innovation and achievement of the best price-performance ratio. In all situations, involving monopolies, or only using as little as one valid tender, offers transparency in the pricing which could be achieved through the legal right to inspect the basis for the bid (Swiss Federal Council, 2018).

The procurement of weapons, ammunition, and services required for defence and security is exempted from the international WTO obligations. Switzerland is using exception when, a) procuring security related goods and services that would preserve Swiss key STIB capabilities, or b) requiring initial and subsequent procurement of goods or services for the ability to integrate procured items into existing systems (Swiss Federal Council, 2018).

If DDPS is concerned with the project's compatibility with foreign policy, it must consult the Federal Department of Foreign Affairs, the Federal Department of Economic Affairs, Education and Research, and relevant State Secretariats (Swiss Federal Council, 2018).

The international armaments market is not an open market, and is governed by national constraints. This could also be applied towards technologies or key components where availability is subject to foreign government approvals and controls (Swiss Federal Council, 2018). The State secretariat for economic affairs (SECO) and the Federal department of foreign affairs are the federal agencies responsible for the export control policy. FODP has to maintain regular dialogue with SECO and the Federal department of foreign affairs in order to mutually consolidate needs. The Export control policy of the Federal government takes into account the security-relevant needs of the AF, and enables the ability to offer Swiss made internationally competitive products and services to other countries (FODP, 2020a).

In summary, the Federal Council, DDPS and FODP outline the Swiss armament strategy which is open to all participants of the global arms trade. The strategy allows the government to seek greater support for domestic STIB, boost Swiss R\&D efforts and domestic 
procurements, request foreign sellers' offsets, enable better information exchange with DI, and define supportive export control policy. All steps allow support and maintenance of the capacity of indigenous DI. Armament procurement system ensures the most economic efficient outcome with local DI engaged to the maximum extent possible. DDPS periodically defines the economic sectors that form the potential core set of STIB which includes, information, communication, and sensor technologies which were defined as security-relevant core technologies in 2020.

\section{Armament life cycle process}

FODP tend to procure previously proven and durable systems instead of systems which have the latest technological advancements. FODP seeks to acquire systems that provide reliable performance over time and offer future upgrades and adaptations (Markowski, 1998).

Armament, military equipment life cycle process in Switzerland consists of the following phases: planning, evaluation, parliamentary deliberations, procurement and introduction, utilization, and decommission. In the planning phase, the capability-oriented approach is used while determining the needs for the Swiss AF. Everything starts with the master plan which is drafted by AF staff. The plan covers an eight year period and details capability needs for the AF to achieve a given mission. The eight year plan is converted into specific medium-to-short term implementation plans with specific coordination measures further used for investment. The plans are submitted for approval to the Head of DDPS. In this step, parliamentary control is executed by firstly having the Parliament approve an annual guarantee and preliminary estimate credits for project planning, trials, and procurement preparation. Next, the Financial Committees of the National Council and the Council of States authorize the DDPS to enter into financial commitments. It is important for the Defence Committees of the two chambers to be informed periodically about developments in the acquisition field so that DDPS has to weigh submitted plans for approval against authorizations granted by the Parliament during the approval process. After plans are endorsed, the AF staff continues with analyses requirements, investment planning, operating costs, specifying the military requirements for future acquisitions, and finally delivering the project charter to FODP. The project charter is approved by the Head of AF staff. FODP considers the initial cost/benefit ratio, engages the industry in the early stage to allow proper preparation for future Swiss AF acquisitions, and briefs the industry on AF capability medium and short term plans (FODP, 2020e). 
In the evaluation phase, FODP plays a major role after it receives the project charter from the AF staff. FODP converts the military requirements into technical specifications and prepares them for the tender procedure. During the pre-evaluation stage, FODP conducts market analysis to look for a potential system list that is later reduced to a shortlist composed of generally three systems. During the evaluation process, in-depth technical, operational, and logistic tests are conducted together with analysis from the commercial angle. Based on these results the National Armaments Director, in consultation with the Chief of the AF, makes a decision regarding a system type. The decision is based on military, technical, and economic aspects over the entire life cycle of the system. From the pre-evaluation to the type selection stage, potential suppliers are competing with each other. Next, technical trials indicate suitability for use by military units. This results in a contract with the relevant industry which comes into effect after being approved by Parliament. In order to acquire simple standard equipment, the process could be shortened if no unwarrantable risks are taken. In the evaluation phase, Defence and Finance Committees are partly involved in the processes (FODP, 2020e).

In the Parliamentary approval phase, AF staff and FODP provides AF Dispatch which includes the Annual armaments programme. Defence committees of the National Council and the Council of States examine proposals. Once the Armament program has been discussed and approved in both Chambers, the Federal Council releases the projects for procurement within the approved financial limits (FODP, 2020e).

Next comes the procurement and introduction phases, at which time FODP conducts procurement, introduces a system for the end user, and remains responsible only until the project reaches full operational capability, a determination made by the Head of AF staff. Following this decision, the AF Logistic Organisation becomes responsible for life cycle management in the utilisation phase. Decisions about prolonged system use are made by the Head of AF staff. If the Chief of the AF or Parliament (depending on system value) decides the system instead needs to be decommissioned, FODP has to either liquidate, sell, or dispose of the system (FODP, 2020e).

FODP is seeking to provide the industry with timely information on the upcoming developments, requirements, and needs of the $\mathrm{AF}$, thus providing an option for active participation. The exchange of information among FODP, AF, domestic and foreign industry, and arms manufacturers is institutionalised. Strategy foresaw that the exchange of data would use newly created or existing cooperation platforms. Swiss DI associations would enable access to existing international networks and markets for Swiss industries. To assess medium and long 
term developments in the area of security-relevant core technologies, Thematic task forces composed of FODP, AF, industry, universities, and research institutes are created. It was previously determined that representatives from the Thematic task force would be involved early in discussions regarding developments and skills which would be required in later in the particular area (FODP, 2020a).

Switzerland follows lengthy sequential procurement procedures wherever it conducts independent arms equipment testing and evaluation after equipment has been used elsewhere. This requirement adds additional costs and time necessary to conduct procurement, as well as the situation in which the equipment received would be either from a previous technology generation or aligned with the strategic needs of other nations. Moreover, replacement and procurement of spare parts may not be possible if the foreign supplier is no longer manufacturing the specific version or model of equipment. An fix for this could be to integrate project teams consisting of representatives from buyers and industry who are responsible for developing new replacement equipment. This way, equipment development, production, and evaluation phases are maintained within a single process. Using this concept, Switzerland would profit from the exchange of experience within international armaments projects, discussion on interoperability, and negotiations regarding stationing, training and logistics support (Borchert \& Eggenberger, 2003).

To summarize, the Swiss armament and military equipment life cycle process consists of multiple stages involving the end users, i.e Swiss AF and local DI (to the maximum extent possible), civilian control elements from Parliament, and FODP. Regardless of any flaws, FODP will be able to procure proven and durable systems with wide upgrade options instead of systems having the latest technological advancements all while conducting lengthy tests and evaluations to achieve final decisions. FODP responsibility ends with the equipment being delivered to the Swiss AF, and starts again once it is decided to decommission equipment or armaments. AF Logistic Organisation is responsible for the equipment's utilization until it is not suitable to use.

\section{Research and Development}

Switzerland spends a sizable amount of budget for R\&D. In 2017, 3.3 percent of the GDP was devoted for R\&D - 22 billion CHF. As Switzerland was overtaken by Israel, South Korea and Sweden, it took fourth place in the world for highest spending for R\&D in 2017 (OECD, 2020). 
$\mathrm{S}+\mathrm{T}$ is assessing technology needs for the Swiss AF in the future-oriented context, by conducting modelling and simulations. $\mathrm{S}+\mathrm{T}$ prioritize research on focus and themes, finance, plans, controls, which it then transfers to the AF's ongoing projects. For that reason, long-term and yearly research plans are made in close coordination with the Swiss AF. The knowledge gained is transferred through workshops, symposia or presentations. In 2020, six major research programmes were ongoing: the reconnaissance and surveillance, communications technology, cyberspace and information, impact, protection and safety, unmanned mobile systems, and technology foresight (figure 4).
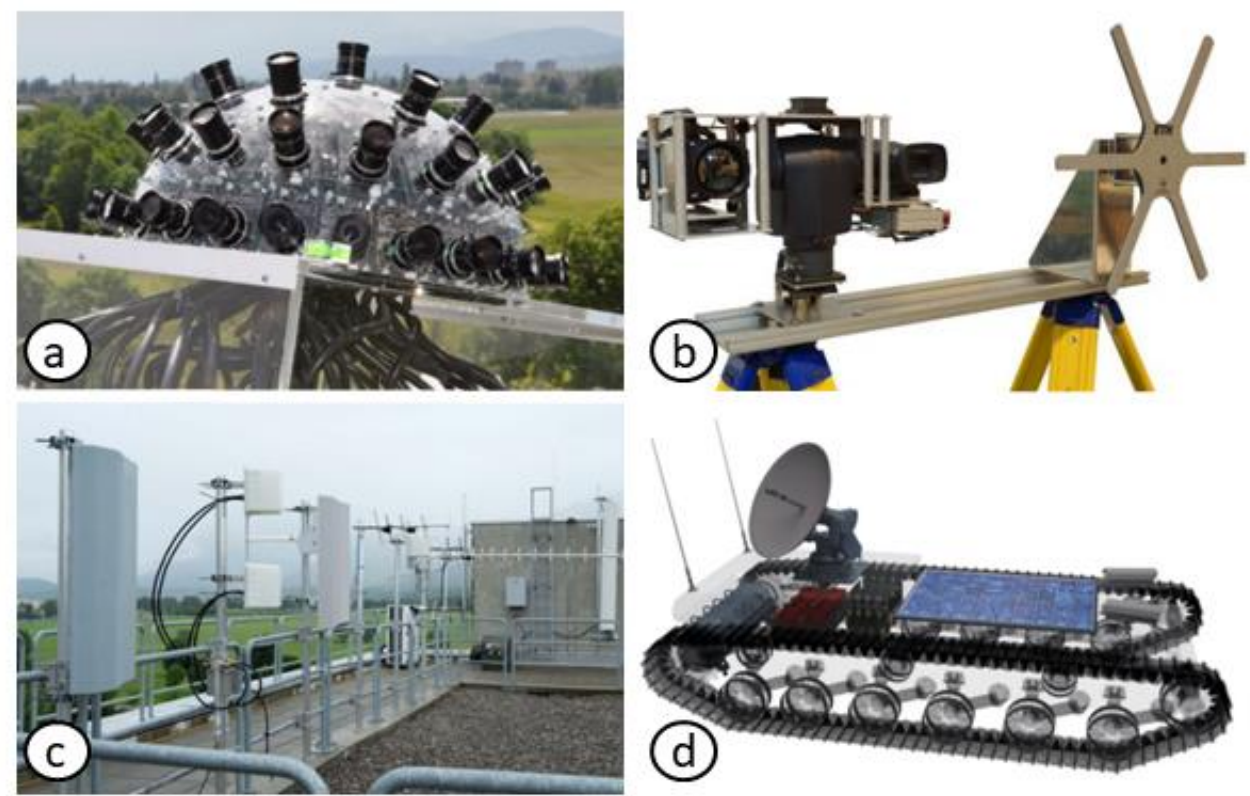

Figure 4. Examples of technologies developed within single programs: GigaEye (a), Multisensor (b), Cognitive radios (c), and Unmanned system (d) (FODP, 2020f)

Technology foresight provides information about the level of maturity of technologies that are optimal for investment and enables awareness of future technological developments. Tracking of technological developments in multiple fields is a challenging effort. Therefore, $\mathrm{S}+\mathrm{T}$ 's Technology foresight program uses a crowd sourcing approach that involves scientific institutions, industry, and Small medium enterprises (SMEs) by collecting information about technologies and their development within an open source platform.

$\mathrm{S}+\mathrm{T}$ is responsible for building partnerships with universities, industries, and organisations from other countries. S+T is in close contact with end users and the planning, procurement, and test centres of the DDPS which allow sustainment of skills, capabilities and development of required expertise. Besides FODP, other federal agencies such as the State secretariat for education, research and innovation, the Swiss innovation agency, the Swiss 
science council, the State secretariat for economic affairs, and the Swiss national science foundation are also engaged in the active promotion of $R \& D$ contracts with Swiss universities, Swiss research institutes, and industry. R\&D contracts in the areas of security relevant core technologies and industrial key capabilities are primarily assigned to the Swiss industry, Swiss universities, and research industries. Various R\&D programmes also include partners, universities, and research institutes from abroad. Strategy notes that international cooperation is the key element for the success of innovation, therefore it is stipulated (FODP, 2020a). The cooperation with start-ups, research institutes, and universities could also take place via a public or private partnership project, or as a part of FODP research contracts (FODP, 2020b).

$\mathrm{S}+\mathrm{T}$ leads a few competence centres, e.g. the Competence centre for non-ionising radiation that takes responsibility for all coordination of electromagnetic emissions and for guaranteeing personal safety at the Competence centre for ammunition and explosives. $\mathrm{S}+\mathrm{T}$ runs several testing facilities, e.g. the Test centre STS0118 responsible for bullet and impact resistance verification for people, vehicles, and buildings, and the Laboratory for high-power electromagnetics. Testing facilities are made available to national and international customers wanting to test systems and components (FODP, 2020g).

R\&D activities could be supported by grants from the Swiss National Science Foundation (SNSF), Foundation pour l'innovation technologique (FIT), and FODP. The SNSF is a leading Swiss institution for promoting scientific research where in 2019, it spent 1,056 million CHF to fund nearly 6,000 projects involving 19,000 researchers. The fund intensively supports scientific research in all academic disciplines. The SNSF is primarily looking for opportunities for the development and international integration of Swiss research where it can promote young researchers and enable research initiatives funded by third parties (SNSF, 2020). FIT provides financial loans for innovative projects being developed at different stages. The type of loan issued depends on the company's age and the loan amounts vary from 100,000 to 500,000 CHF. The FIT finances only establishments located in Vaud canton. From its creation in 1994 until 2019, FIT supported 191 companies with a total amount of 39 million CHF. In 2019, 73 percent of the companies financed still existed. Moreover, at least 20 start-ups supported by FIT are still rated in the top 100 Best Swiss start up category (FIT, 2021).

The Campus concept which is run by FODP S+T unit could be one of the ways to gain and retain knowledge in a particular $R \& D$ area and to develop concepts and prototypes. Currently, S+T runs Cyber Defence Campus in collaboration with other Swiss Departments, scientific institutions, and businesses. The campus is guided by the expert group, tracks 
developments in this particular area, cooperates with other countries, develops and tests cyber technologies, and promotes and attacks talents of Master, PhD and Postdoc level. In 2020, Campus launched a call for the Cyber start up challenge in the field of investigating cyber threats. As a result, the company CounterCraft was announced the winner out of 22 international start-ups, and will implement a proof of concept tailored to the Swiss AF in 2021 (FODP, 2021).

In 2020, Switzerland built a reputation which resulted in it being labelled the Silicon Valley of robotics. Therefore, it is no surprise you can find the Swiss drone and robotics centre (SDRC) in the DDPS structure. SDRC was founded in 2017 by FODP and the Swiss AF and is currently managed by S+T. SDRC focuses only on topics related to robotics for security tasks. Every year, the SDRC initiates multiple research projects and studies carried out by academic institutions and industry (FODP, 2020h).

In summary, Switzerland is spending the most on R\&D in the world; e.g. in 2017 Switzerland spent 22 billion CHF - 3.3 percent of GDP and was ranked fourth in the world accordingly. There are multiple Swiss institutions taking care of promoting science and ensuring there are better linkages between universities, research institutes, and industry. FODP has its own structural element, S+T, which was designed to develop partnerships with universities, industry, and organisations from other countries. S+T is in close contact with end users, engaged in the planning and procurement processes, and has links to test and competence centres of the DDPS. This allows S+T to sustain skills and capabilities, and to develop required expertise in six major research programmes. Defence-related R\&D activities are supported not only by FODP, but also by grants from SNSF and FIT. S+T runs different Defence Campuses that help to track developments in a particular area, to cooperate with other countries, to develop and test technologies, and to promote and attract talents at Master, $\mathrm{PhD}$ and Postdoc levels. As Switzerland continues to build its reputation of being the Silicon Valley of robotics, FODP contributes to the defence R\&D sector where $\mathrm{S}+\mathrm{T}$ runs the Swiss drone and robotics centre. Swiss AF also supports this effort.

\section{Offsets}

Swiss compensation through offsets is requested because procurements of armaments outside the country lead to a potential loss in sales for Swiss companies. This way, the Swiss economy benefits from defence acquisition for the Swiss AF (FODP, 2019). DDPS has to work closely with the industry organisations and interest groups and keep them informed at an early stage of offset implementation. This is one of the prerequisites for the successful 
implementation of offset transactions. Additionally, Swiss Government first seeks for the Swiss industry involved in offset transaction to be competitive, and then, to be able to generate additional value after the offset deal is completed. Swiss Federal Council highlights that 'offset transactions must not be used to pursue policies to maintain structures.' The Federal Council delegates DDPS to manage offsets in a transparent way and to have proper management and controlling instruments available (Swiss Federal Council, 2018)

Since Switzerland is not an EU member, it is not obliged to follow strict offset policies. Switzerland's policy on offsets is on the pro side as it allows for transfer investments to the country, for strengthening the country's industrial base, for developing economic relations with other countries, for preserving existing and acquired new know-how, for generating additional export volumes for Swiss enterprises, and lastly, for preserving jobs (FODP, 2019). The Swiss Government seeks 100 percent of direct offset from contract value while also hoping to 'create capacities or know-how contributing to autonomous maintenance, value retention, or for value enhancement of a system and for core capabilities of industries.' Indirect offsets are also at 100 percent value; however, there could be predictable additional requirements. Indirect offsets are considered if 'they open up new markets to competitive Swiss industry, give access to advanced technologies, ensure the preservation and/or development of additional know-how, or lead to additional contract and export volumes'(FODP, 2019).

Generally, offsets in Switzerland are implemented during major arms acquisitions. It is sought in for at least 60 percent of the total offset obligation to be realised within indigenous DI in Switzerland, with 20 percent or more of the total offset obligation being realised as a direct offset. For better contract coordination purposes, the prime contractor is required to establish a coordination office in Switzerland. Contractual penalties may apply if offset agreement is not followed in which contractual penalties of at least 5 percent of the non-fulfilled portion may be incurred. Furthermore, failure to fulfil contractual offset obligations is an assessment criterion in defence procurements (FODP, 2019).

Offsets are implemented in five stages. During the first planning/conceptual stage, possible offset options are assessed within a specific AF procurement project. At this point, relevant Swiss DI are indicating which capability gaps could be filled with the help of offsets, or which DIs could be promoted. Moreover, the requirements for individual offset programmes are defined based on the Industrial participation strategy of the Armament policy of the Federal Council. This is followed by precise requirements for offsets which are drawn and forwarded for competing enterprises and industry partners. In the second - draft contract stage, 
procurement contracts with offset agreements are prepared and assessed, allowing for the extent of offset to be foreseen. In the third stage - preparation, contracts are approved after the Armament programme has been confirmed by the Parliament. In the fourth - implementation stage, the winning bidder / prime contractor establishes a contract with a Swiss company, or companies, to implement an offset agreement. The monitoring of indirect offset implementation is conducted by the Berne offset office which is financed by the Swiss beneficiaries of an offset transaction. In case of a direct offset implementation, FODP controls the progress. In the last follow-up stage, the experience gained through the process is analysed and used for future offset deals (FODP, 2019).

The Annual offset register provides valuable details on procurement projects, implementation timelines, foreign suppliers, local beneficiaries, and any regional offset distribution. The government aims to ensure overall offset allocation is provided geographically among linguistic regions in Switzerland: 65 percent to German, 30 percent to French, and 5 percent to the Italian speaking region (FODP, 2020c).

To epitomize the situation, Switzerland seeks out offset solutions when arms or equipment is procured from a foreign seller, and offsets are expected to be at 100 percent of procurement value. DDPS has the ultimate responsibility of managing offsets in a transparent way to ensure proper management is being carried out. All offset implementation procedures are clearly defined in order to allow Swiss authorities to attain optimal results from offset implementation: Swiss DI involved in an offset transaction has to be competitive and able to result in added value once the offset deal is complete.

\section{Swiss defence industry}

The restructuring of Swiss DI that lead to downsizing, mergers, and acquisitions leading to a de facto situation started in 1990. The MOWAG Company was acquired by General Motors and later transferred to General Dynamics. Oerlicon Contraves was acquired by Rheinmetall from Germany. Swiss SIG was sold to Swiss Arms and two other entrepreneurs (Hartley, 2019). In similar fashion, Swiss DI started to expand civilian and dual-use technology production and opted to follow other rationalisation measures. Export oriented companies such as Oerlikon Contraves have refocused on niche markets and secured orders through the membership of international business networks and marketing consortia. Smaller companies, e.g. MOWAG AG, the Swiss Industrial Company (SIC), Recta SA, Leica, and Omnisec AG also focused on 
niche markets - in the development of wheeled armoured vehicles, small arms, precision instruments, and cryptology (Markowski, 1998).

SECO provides annual statistics on arms exports. A court case won against SECO by journal WOZ helped to reveal more contemporary data on Swiss made arms exports, DI locations (figure 5), their specialities, and turnaround (Jirát, Surber, \& Bamert, 2020).

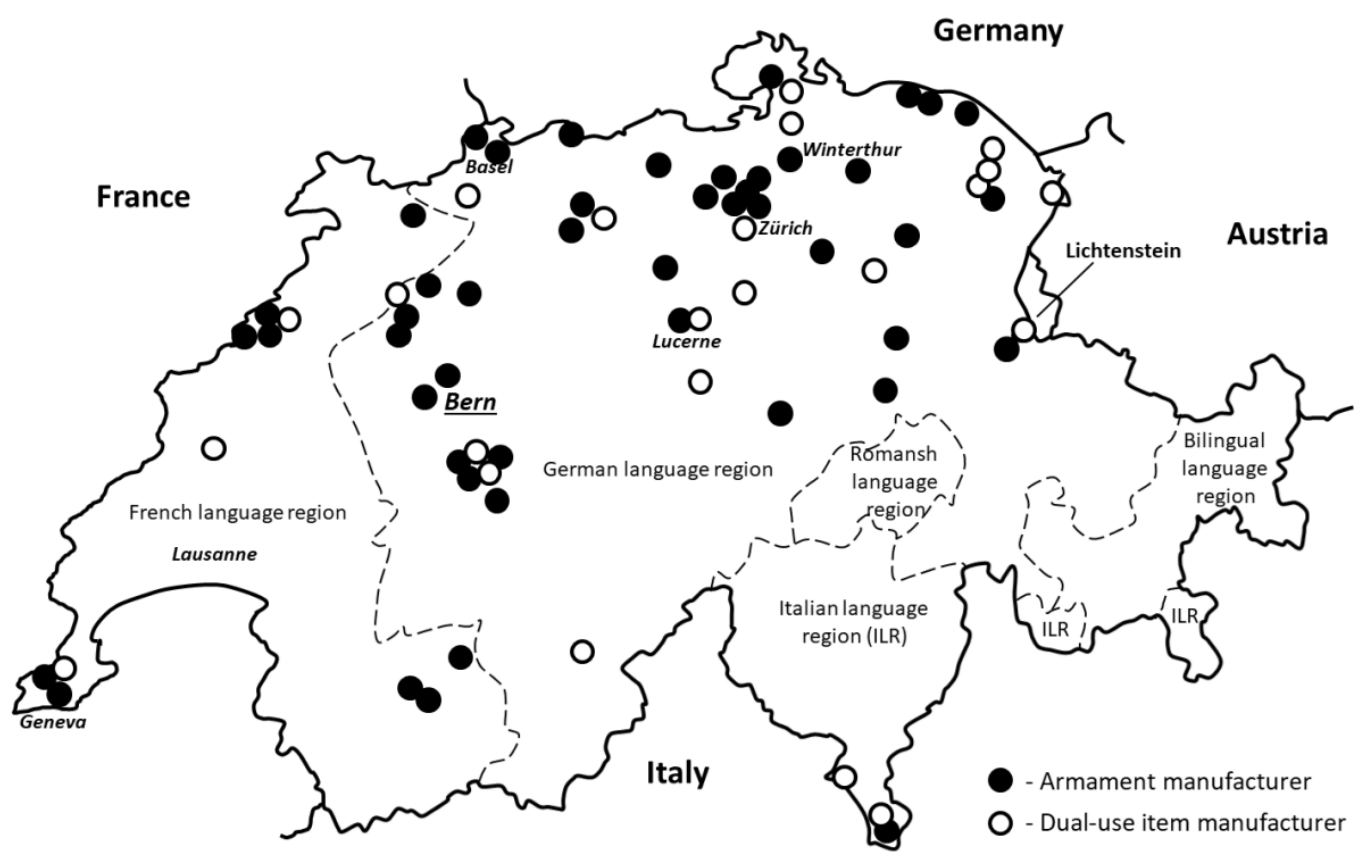

Figure 5. The location of Swiss arms, defence items, and dual-use material production sites (Federal Statistical Office, 2021; Jirát et al., 2020)

Swiss DI is located in different speaking regions with the biggest amount, nearly 65 percent, being located in German, 30 percent in French, and 5 percent in Italian speaking areas.

Swiss Avionics, Security, and DI is composed of a mix of around 100 large and mediumsize companies consisting of SMEs, subsidiaries of larger multinational manufacturers groups, overall employing more than 10,000 personnel. Some of the profiles for these companies show that they are dedicated to manufacturing armaments, however, a large portion of the companies produce dual use products along with the armaments they produce, i.e. varieties of equipment, assembly parts, and provisions of special and engineering services. Some companies are also parts and equipment suppliers for domestic and foreign original equipment manufacturers (Giger, 2013). Employment in DI fluctuates due to various country arms policies, the situation in global arms markets, and national defence spending. In the worst observed scenario which occurred in 1990 there were only around 3,000 workers employed, but nevertheless, as export 
markets continued expanding, Swiss DI managed to gain its own momentum and reached 10,000 employees in 2013 (Hartley, 2019)

Switzerland does not have large scale STIB. The majority of defence system suppliers and system integrators established in Switzerland are owned by foreign companies. In most cases, these are former Swiss companies that have been acquired by foreign capital. The majority of Swiss companies in STIB are "made up of the knowledge and skills of innovative small and medium-sized private enterprises that partly manufacture technologically advanced subsystems or individual components for overall military and civilian systems.' It is clear that Swiss companies can't maintain their position in the arms market unless they become leaders in technology and by manufacturing reliable and convincing products (Swiss Federal Council, 2018).

In 2019, Swiss companies exported defence articles to 71 countries for a total value of 728 million CHF. Exports increased by 43 percent compared to the previous year. Arms export shares compose 0.23 percent of total Swiss exports in 2019 (figure 6). The latest increase in exports is connected to the latest Danish, Romanian, and Bangladeshi procurements (annex 1).

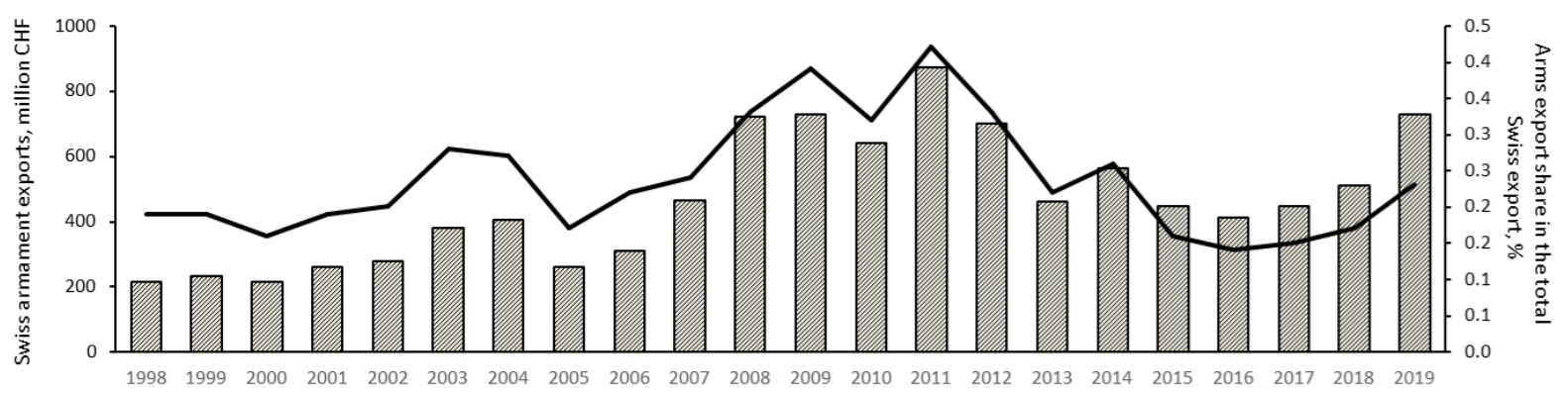

Figure 6. Value of Swiss armament exports and its share in the total Swiss export (SIPRI, 2020b)

The biggest exports for 2019 included wheeled armoured vehicles delivered to Denmark for 150 million CHF and to Romania for 111 million CHF, ammunition delivered to Germany for 68 million CHF, and air defence systems with ammunition delivered to Bangladesh for 55 million CHF (State Secretariat for Economic Affairs, 2020). The top exporters were RUAG Ammotec, RWM Schweiz, RWM Zaugg, last two belonging to Rheinmetall and GDELSMOWAG (Swissinfo.ch, 2020). The SIPRI Transfer of a major weapons database (annex 2) indicates that the following defence articles manufactured in Switzerland were the most exported: air defence systems - Skyguard, Skyshield-35; fire control radar - Fieldguard-3; trainer aircrafts - PC21, MD-3-160, PC-7 Turbo Trainer; aircrafts - PC9; PC12, PC-6 Turbo Porter; armoured personnel carrier - Piranha; anti-aircraft guns - GDF, GDM-008; and vehicles 
- DURO 3, Eagle. In line with the production of new equipment, Swiss DI took part in modernization and sales of old equipment including the most popular items which consisted of: helicopter - SA-316B Alouette-3; aircrafts - F-5E Tiger-2, Hawk-60, Hunter; tank chassis Leopard 2, PiPz-3 Kodiak; and artillery units - M-109A1, M-87 (SIPRI, 2021).

As the Swiss DI base is very thin, Switzerland has to focus only on its own development work and building of required competencies in several sectors. At the same time, Swiss DI has to be aware that nonessential modifications of Swiss AF equipment, the so-called 'goldplating', will be avoided as using off-the-shelf products make more sense economically (Borchert \& Eggenberger, 2003).

To summarize, the shifts of the global arms market in the 1990s challenged Swiss DI. This led to a temporary slowdown, optimization, and series of mergers and acquisitions. The outcome was that Swiss DI expanded their markets abroad, moved to the production of doubleuse items, and focused on certain defence niches. This led to the complete rebirth of Swiss DI in 2013 when employment levels similar to those the 1990s were reached. Increasing arms exports into new markets will stimulate the rise of Swiss DI as they are currently composed of more than 100 companies that are located in different Swiss cantons. The majority of Swiss DI manufacturing technologically advanced subsystems or individual components are able to develop systems, with only a few exceptions - RUAG and Rheinmetall, which are already large companies.

\subsection{RUAG}

RUAG was formed in 1998 and is focused on aeronautics and defence engineering. It is also an industrial partner for Swiss AF that upgrades and maintains weapon and defence systems (Hartley, 2019). In the last two decades, RUAG Holding AG was listed in the SIPRI Top 100 arms producing and military servicing companies in the world list (table 2). No other Swiss companies were included on the list.

Table 2. RUAG Details from theList of SIPRI Top 100 (SIPRI, 2019)

\begin{tabular}{|c|c|c|c|c|c|c|c|c|c|c|c|c|c|c|c|c|c|}
\hline Year & 용 & $\overbrace{\mathscr{\gamma}}$ & ষ্ণ & 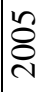 & ঠ্ণ & 용 & 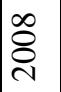 & 용 & $\stackrel{0}{\stackrel{0}{0}}$ & $\overline{\bar{\partial}}$ & 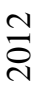 & $\frac{m}{\stackrel{2}{d}}$ & $\underset{\circlearrowright}{\stackrel{৩}{ঠ}}$ & $\stackrel{n}{\frac{n}{2}}$ & $\frac{b}{\infty}$ & 홍 & $\frac{\infty}{\stackrel{\nu}{\nu}}$ \\
\hline Place & 71 & 67 & 69 & 76 & 89 & 91 & 78 & 92 & 83 & 77 & 83 & 96 & 98 & 95 & 96 & 95 & 95 \\
\hline Sales, million USD & $\underset{f}{\stackrel{P}{f}}$ & ్ర & त్ర & in & 㝒 & $\begin{array}{l}\infty \\
\infty \\
i\end{array}$ & $\frac{8}{2}$ & 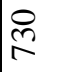 & $\underset{\infty}{\infty}$ & $\stackrel{ }{+}$ & ๙ૅ & $\stackrel{\infty}{\infty}$ & $\underset{\infty}{\stackrel{+}{+}}$ & $\underset{\infty}{\infty}$ & $\underset{\infty}{\infty}$ & $\frac{尺}{\infty}$ & ஓ̊ \\
\hline
\end{tabular}


Based on the Swiss Federal Council's decision made on June 27, 2018, the unbundling company of RUAG, which was performing services for the Swiss AF, was able to separate from the other business areas operating in the international environment in 2020. According to initial estimates, the entire reorganization was expected to cost around 65 million CHF once complete. A new enterprise - MRO Holding, and its subsidiary, MRO Switzerland, were also responsible for providing services to the Swiss AF. MRO Switzerland is now generally responsible for the activities previously carried out by RUAG Defence and RUAG Aviation. MRO Holding is also comprised of the RUAG International, a new company that brings services to the market while covering all defence areas or conducting essential third-party business with the customers besides the Swiss AF. RUAG Space, RUAG Aerostructures, RUAG Ammotec, and Cyber make up RUAG International. As RUAG International covers multiple industrial areas, it has to streamline its portfolio or it would lack the resources necessary to continue at a consistent pace. For that reason, RUAG International has to continue financing developments in the core areas, sell off the areas which are of less importance, and/or attract capital market. From the latest press releases, it is clear the company will focus its activities on space and aerostructures, optimizing, preparing, and becoming privatized within the upcoming 5 years. It is important to note that it is already the second transformation of RUAG. The first one occurred in the 1990s when four Swiss companies were forced to merge into RUAG due to declining domestic and international markets (RUAG International, 2018).

In summary, RUAG is the only Swiss DI company highlighted in the SIPRI Top 100 list that managed to sustain its position on the SIPRI list over the last two decades. The latest RUAG reorganization starting in 2020 aims to split the company into two parts: MRO Switzerland focusing on Swiss AF needs, and RUAG International - providing services to international customers and focusing on space and aerostructures. RUAG International still has to streamline its portfolio even though some privatization, sell-off, and capital attraction options remain available.

\section{Swiss defence industry associations}

Officially, FODP cooperates with two Swiss industry associations, Swissmem and GRPM. Swissmem unites large companies and SMEs in mechanical and electrical engineering industries and related technology-oriented sectors. Swissmem consolidates around 1200 companies, including some like Rheinmetall Air Defence AG, RWM Schweiz AG, General Dynamics European Land Systems-Mowag GmbH, and SaabBofors Dynamics Switzerland 
which are working primarily on defence sector initiatives. Swissmem provides advice on employment, commercial, contract and environmental law, and also shares knowledge on technology transfer and offers market oriented training. Swissmem operates specialist groups which consist of various experience sharing forums that provide opportunities for members to discuss technical matters or to work on joint projects. Swissmem helps companies to increase their competiveness, handles matters with politicians, the government, and the public, it promotes constructive social partnership, and it negotiates the terms of the collective employment agreement for DI with social partners (Swissmem, 2021). GRPM facilitates access to the Governmental orders for French-speaking defence and security equipment manufacturers. GRPM serves as a meeting platform among members, Swiss AF planners, and governmental acquisition bodies. GRPM unites more than 60 companies, participates in the monitoring of compensatory cases, has certain awareness in the particular areas of cutting edge knowhow, favours the Swiss Buy Act, and supports for the ability for adequate compensatory business to be conducted in French-speaking regions. The biggest companies belonging to GRPM are RUAG, Liebherr Machines Bulles SA, Groupe Elca, and Swiss Securitas Group (GRPM, 2020).

At the end of 2020, the biggest Aerospace and DI Association of Europe (ASD) united 18 major European companies and 23 National Associations from 18 European countries. The Swiss DI and the national defence associations do not belong to the ASD. ASD is treated as an important hub of influence and knowledge by EDA and other EU institutions (ASD, 2020). Currently, EDA is dealing with only one Swiss National DI association - Swissmem.

To be specific, FODP officially cooperates with two Swiss industry associations uniting more than 1260 different Swiss companies. Only some members of Swissmem belong to the DI sector. However, both industry associations provide advice in multiple fields, share knowledge through different forums, enable joint projects, deal with politicians in a centralized way, and represent members in meetings with social partners. Moreover, both associations host meetings between DI, Swiss AF planners, and governmental acquisition bodies. In regards to a global scale, none of the Swiss associations belong to ASD.

\section{International collaboration}

The scope of Swiss international collaboration in the arms sphere is primarily based on the needs of the Swiss AF. During the planning phase, the AF identifies its skills, gaps, and technology needs and works with FODP to define its procurement needs. Timely considerations 
within DDPS allow using the potential of international collaboration more effectively. The trends of DI consolidation, limited availability for security technology skills, and limited resources indicate a need to "collaborate more closely with other countries and seek partnerships within the framework of international organisations.' Collaboration could be conducted more practically in any step of arms or services development, e.g. during exchanges of information, during $\mathrm{R} \& \mathrm{D}$, during collaborative procurement of materials, combined logistics, or testing, and even during negotiating contractual agreements with external industrial service providers (Swiss Federal Council, 2018).

The Swiss Federal Council encourages the idea of pursuing a strategy of increased international collaboration for armament as well as developing limited national skills and capabilities in this field. This could assist in remaining supplied during extraordinary situations and increase the security level of supplies. The Swiss Federal Council guides the DDPS to identify potential collaborations during the armament procurement process, and to monitor trends in science, technology, and the markets (Swiss Federal Council, 2018).

Armament strategy encourages cooperation with selected international partners that would enable 'FODP, Swiss industry, universities, and research institutes to participate in international research projects as well as gain access to foreign technologies and markets.' The scope of cooperation should neither hamper 'autonomous operational capability of the AF', nor 'violate regulations of neutrality or international law.' Domestic and international cooperation in arms and system procurement could allow for achieving economies of a more prosperous scale, especially in the areas which enable STIB to gain access to foreign markets. Intensive cooperation could help in preservation of value, beneficial extension of life, and an enhanced combat value of military systems. Cooperation would be achieved via participation in NATO, EU, EDA, and cooperative initiatives and bilateral and multilateral agreements (FODP, 2020a).

The means of closer cooperation with Europe in the armaments sphere would pose a challenge to Parliament as individual members would no longer vote simply on armament programmes, but could instead consider an armament program as a tool to acquire knowledge or to be used as a means of influence while participating in joint European projects requiring funds and manpower (Borchert \& Eggenberger, 2003).

To summarize, the international collaboration in the DI field remains a priority for Federal government as it likely enables access to foreign technologies and markets. FODP, as a responsible entity in the DI field, has identified potential cooperation venues such as NATO, the EU, and the EDA wherein the cooperation is based on bilateral and multilateral agreements. 
It is assessed that DI skill, gap, and technology needs could be adjusted utilizing international collaboration tools such as exchanges of information, $\mathrm{R} \& \mathrm{D}$, procurement of materials, improvements towards logistics, improved testing, and the negotiation of contractual agreements.

\section{Conclusion}

Switzerland continues with a similar supportive strategy for the local defence industry as Stefan Markowski defined it in 1998. Switzerland promotes local companies in national defence procurements, uses offsets extensively to gain technologies and knowledge, and protects certain defence industry niches. It is highly likely that the efforts mentioned contributed to the revitalization of Swiss defence industry after a sharp decline in the 1990s. More importantly, all offset implementation procedures are clearly defined as Swiss authorities are looking for optimal results from offset implementation: Swiss defence industry involved in offset transaction has to be competitive and able to generate additional value after the offset deal is over.

Contemporary Swiss defence industry is composed of more than 100 companies mostly manufacturing technologically advanced subsystems or individual components with only few exceptions, e.g. RUAG and Rheinmetall that are able to develop entire systems. Regardless of the fact that the Swiss defence industry exports less than one percent of total country exports, the Swiss government ensures proper support of this economic sector in a coherent manner. Additionally, the Swiss government looks for efficient ways to boost defence industry and is ready for big reforms, e.g. RUAG's reorganization in 2020 aimed to split the company into two parts: MRO Switzerland - focusing on Swiss AF needs, and RUAG International - providing services to international customers and focusing on space and aerostructure niches.

Switzerland protects and supports developments of its own STIB, key scientific technical competencies, and key capabilities of the indigenous defence industry. Therefore, DDPS is in charge of periodically defining the economic sectors that form the potential core set of STIB. Universities, research institutes, and companies contribute to the development of the competencies in each identified area. Switzerland has an exclusive R\&D support environment, including defence related R\&D initiatives that are supported by multiple sources. FODP has its own structural element $-\mathrm{S}+\mathrm{T}$ engaged in sustaining skills, capabilities, and developing required expertise in six major research programmes. S+T element's annual budget for 2021 is 32.2 million CHF. S+T employs innovative approaches to enhance defence R\&D by running 
different Defence Campuses, testing and competence centres, and promoting and attracting talents of Master, PhD, and Postdoc levels.

Acknowledgements. Many thanks go to the scholars who took time to review and evaluate my paper uploaded in the preprint service. This favour would allow improving the paper prior to presenting it in the Annual ECPR General Conference. I would also like to extend an appreciative thank you to Mr. Will Gonzales (HQ MNC NE) for initial draft paper review and English proofreading.

\section{Notes}

USD - CHF rate used in the text $1.00-1.00$

\section{References}

ASD. (2020). Members. Retrieved from https://www.asd-europe.org/about-us/members

Borchert, H., \& Eggenberger, R. (2003). European security defence policy, role specialization and pooling of resources: The EU's need for action and what it means for Switzerland. Contemporary Security Policy, 24(3), 1-25.

DDPS. (2020a). The army in numbers. Retrieved from https://www.vbs.admin.ch/de/vbs/zahlen-fakten/armee.html

DDPS. (2020b). Federal intelligence service. Retrieved from https://www.vbs.admin.ch/en/ddps/organisation/administrative-units/intelligenceservice.html

DDPS. (2021a). The federal office for civil protection. Retrieved from https://www.babs.admin.ch/en/home.html

DDPS. (2021b). Federal office for sport. Retrieved from https://www.baspo.admin.ch/de/home.html

DDPS. (2021c). Federal office of topography . Retrieved from https://www.swisstopo.admin.ch/en/home.html

DDPS. (2021d). General secretariat. Retrieved from https://www.vbs.admin.ch/de/vbs/organisation/verwaltungseinheiten/generalsekretariat.ht $\underline{\mathrm{ml}}$

DDPS. (2021e). Office of the armed forces attorney general. Retrieved from https://www.oa.admin.ch/en/home.html

DDPS. (2021f). Organization. Retrieved from https://www.vbs.admin.ch/de/vbs/organisation.html

EDA. (2012). Indoor navigation for soldiers. Retrieved from https://eda.europa.eu/infohub/press-centre/latest-news/2012/01/23/Indoor_Navigation_for_Soldiers

EDA. (2020). Member states. Retrieved from https://eda.europa.eu/Aboutus/who-weare/member-states

Federal Statistical Office. (2021). Population. Retrieved from https://www.bfs.admin.ch/bfs/en/home/statistics/population.html

FIT. (2021). Presentation. Retrieved from https://fondation-fit.ch/en/who-is-fit/

FODP. (2019). Offset policy. Retrieved from https://www.ar.admin.ch/content/arinternet/de/beschaffung/ruestungspolitik-desbundesrates/offset/_jcr_content/contentPar/downloadlist/downloadItems/41_1580888860 208.download/Offset-Policy\%20D\%202019\%20.pdf 
FODP. (2020a). Armaments strategy. Retrieved from https://www.ar.admin.ch/content/arinternet/en/beschaffung/ruestungspolitik-desbundesrates/_jcr_content/contentPar/downloadlist/downloadItems/231_1579257320665. download/en_ruestungsstrategie_2020.pdf.

FODP. (2020b). Cyber Defence campus. Retrieved from https://www.ar.admin.ch/de/armasuisse-wissenschaft-und-technologie-w-t/cyberdefence campus.html

FODP. (2020c). Offset register as of 30.06.2020. Retrieved from https://www.ar.admin.ch/content/ar-internet/en/beschaffung/ruestungspolitik-desbundesrates/offset/offsetregister/_jcr_content/contentPar/downloadlist/downloadItems/28 4_1594284272068.download/en_\%200ffset-Register\%20per\%2030.06.2020.pdf.

FODP. (2020d). Organization. Retrieved from https://www.ar.admin.ch/en/ueberarmasuisse/organisation.html\#ui-collapse-377

FODP. (2020e). Procurement program. Retrieved from https://www.ar.admin.ch/en/dokumente-und-publikationen/ruestungsablauf.html

FODP. (2020f). Research management. Retrieved from https://www.ar.admin.ch/en/armasuisse-wissenschaft-und-technologie-wt/forschungsmanagement.html

FODP. (2020g). Science and technology S+T. Retrieved from https://www.ar.admin.ch/en/armasuisse-wissenschaft-und-technologie-w-t/home.html

FODP. (2020h). SDRZ - Swiss drone and robotics centre. Retrieved from https://www.ar.admin.ch/de/armasuisse-wissenschaft-und-technologie-w-t/sdrz.html

FODP. (2021). "Cyber Start-up challenge 2020": Start-up company CounterCraft convinces jury. Retrieved from https://www.vbs.admin.ch/content/vbsinternet/de/home.detail.nsb.html/82083.html

Giger, E. B. (2013). Defence industry of Switzerland. Retrieved from https://armadainternational.com/wp-content/uploads/2018/01/Defence-Swiss-BookletFinal-2013.pdf

GRPM. (2020). Profile. Retrieved from http://www.grpm.ch/association/profil

Hartley, K. (2019). 14. Switzerland. In K. Hartley, \& J. Belin (Eds.), The economics of the global defence industry, Routledge.

Jirát, V. J., Surber, K. \& Bamert, M. (2020). Waffenfabrik schweiz. Retrieved from https://www.woz.ch/2029/ruestungsexporte/waffenfabrik-schweiz

Kurečić, P., Kozina, G., \& Kokotović, F. (2017). Revisiting the definition of small state through the use of relational and quantitative criteria. Paper presented at the 19th International Scientific Conference on Economic and Social Development,

Markowski, S. (1998). Switzerland-The pragmatic approach to defence procurement. Defence and Peace Economics, 9(1-2), 99-118.

Markowski, S., \& Hall, P. (2003). Defence procurement and industry development: Some lessons from Australia. Institute for Defence Resources Management, RMC, IDRM/IGRD, 6

Markowski, S., \& Wylie, R. (2007). The emergence of European defence and defence industry policies. Security Challenges, 3(2), 31-51.

NATO. (2018). Relations with Switzerland. Retrieved from https://www.nato.int/cps/en/natohq/topics_52129.htm

OECD. (2020). Switzerland. Retrieved from https://data.oecd.org/switzerland.htm\#profileinnovationandtechnology 
RUAG International. (2018). Federal council's decision on the concept of "unbundling RUAG". Retrieved from https://www.ruag.com/en/news/federal-councils-decisionconcept-unbundling-ruag

SIPRI. (2019). The SIPRI top 100 arms-producing and military services companies, 2018. Retrieved from https://www.sipri.org/sites/default/files/201912/1912_fs_top_100_2018_0.pdf

SIPRI. (2020a). Global arms industry: Sales by the top 25 companies up 8.5 per cent; big players active in global south. Retrieved from https://www.sipri.org/media/pressrelease/2020/global-arms-industry-sales-top-25-companies-85-cent-big-players-activeglobal-south

SIPRI. (2020b). National reports: Switzerland. Retrieved from https://www.sipri.org/databases/national-reports/Switzerland

SIPRI. (2020c). SIPRI military expenditure database. Retrieved from https://www.sipri.org/databases/milex

SIPRI. (2020d). Trends in international arms transfers, 2019. Retrieved from https://www.sipri.org/sites/default/files/2020-03/fs_2003_at_2019.pdf

SIPRI. (2021). Trade registers. Retrieved from http://armstrade.sipri.org/armstrade/page/trade_register.php

SNSF. (2020). Profile. Retrieved from http://www.snf.ch/en/theSNSF/profile/Pages/default.aspx

State Secretariat for Economic Affairs. (2020). Export of war material in 2019. Retrieved from https://www.seco.admin.ch/seco/en/home/seco/nsb-news.msg-id-78277.html

Swiss AF. (2020). Swiss armed forces - organisation and structure. Retrieved from https://www.vtg.admin.ch/en/die-schweizer-armee/gliederung.html

Swiss Federal Council. (2018). Principles of the Swiss federal council for the armament policy of the DDPS. Retrieved from https://www.ar.admin.ch/content/arinternet/en/beschaffung/ruestungspolitik-desbundesrates/_jcr_content/contentPar/downloadlist/downloadItems/401_1457687102317. download/Principles $\% 20$ of $\% 20$ the $\% 20$ Swiss $\% 20$ Federal $\% 20$ Council $\% 20$ for $\% 20$ the $\% 20$ Armament\%20Policy\%20of\%20the\%20D..pdf

Swissinfo.ch. (2019). Switzerland joins cyber defence unit in Estonia. Retrieved from https://www.swissinfo.ch/eng/cyber-risks-_switzerland-joins-cyber-defence-unit-inestonia-/44980738

Swissinfo.ch. (2020). Biggest Swiss-based arms manufacturers revealed. Retrieved from https://www.swissinfo.ch/eng/biggest-swiss-based-arms-manufacturersrevealed/45907772

Swissmem. (2021). The Swiss association of mechanical and electrical engineering industries. Retrieved from https://www.swissmem.ch/en/the-swiss-association-of-mechanical-andelectrical-engineering-industries.html

The Wassenaar Arrangement. (2020). Control lists. Retrieved from https://www.wassenaar.org/control-lists/

The World Bank. (2021). Military expenditure (\% of GDP) - Switzerland. Retrieved from https://data.worldbank.org/indicator/MS.MIL.XPND.GD.ZS?locations=CH\&view=chart 
Annex 1

Top 10 countries utilizing Swiss arms exports 2000-2019 (SIPRI, 2020b)

\begin{tabular}{|c|c|c|c|c|c|c|c|c|c|c|c|c|c|c|c|c|c|c|c|c|}
\hline \multirow[b]{2}{*}{ Country } & \multicolumn{20}{|c|}{ Year } \\
\hline & ஓ্ণ & ঠ্ণু & $\stackrel{ }{ᄋ}$ & 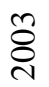 & $\underset{ঠ}{ঠ}$ & 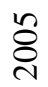 & ঠ̊ঠ & 용 & $\stackrel{\infty}{\bigodot}$ & $\stackrel{\text { }}{ᄋ}$ & $\stackrel{\circ}{\frac{0}{\circ}}$ & $\overline{\bar{\delta}}$ & $\frac{\sim}{ٍ}$ & $\frac{m}{\rho}$ & $\frac{\Xi}{\stackrel{\sim}{D}}$ & $\frac{n}{0}$ & $\frac{0}{0}$ & $\bar{\delta}$ & $\stackrel{\infty}{\stackrel{\sim}{0}}$ & 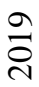 \\
\hline Argentina & $\bullet$ & & & & & & & & & & & & & & & & & & & \\
\hline Australia & & & & & & & & & & & & & & & & & & & & $\bullet$ \\
\hline Austria & & & $\bullet$ & $\bullet$ & $\bullet$ & & & & & & & & & & & & & & & \\
\hline Bahrein & $\bullet$ & & & & & & & & & & & & & & $\bullet$ & & & & & \\
\hline Bangladesh & & & & & & & & & & & & & & & & & & & & - \\
\hline Belgium & & & & & & & & & $\bullet$ & $\bullet$ & $\bullet$ & $\bullet$ & & & & & & & & \\
\hline Botswana & & & & $\bullet$ & $\bullet$ & & & & & & & & & & & & & & & \\
\hline Brazil & & & & & & & & & & & & & & $\bullet$ & $\bullet$ & $\bullet$ & & $\bullet$ & & \\
\hline Canada & $\bullet$ & & & & & & & & & & & & & & & & & & & \\
\hline Chile & & & & & & & $\bullet$ & & & & & & & & & & & & & \\
\hline Denmark & $\bullet$ & & & & & $\bullet$ & $\bullet$ & $\bullet$ & $\bullet$ & $\bullet$ & $\bullet$ & & & & & & $\bullet$ & & $\bullet$ & $\bullet$ \\
\hline Finland & & & & & & & $\bullet$ & & $\bullet$ & & & & & & & & & & & \\
\hline France & & $\bullet$ & $\bullet$ & $\bullet$ & & $\bullet$ & $\bullet$ & $\bullet$ & & - & $\bullet$ & & • & $\bullet$ & $\bullet$ & & $\bullet$ & $\bullet$ & $\bullet$ & - \\
\hline Germany & $\bullet$ & $\bullet$ & $\bullet$ & $\bullet$ & $\bullet$ & $\bullet$ & $\bullet$ & $\bullet$ & $\bullet$ & $\bullet$ & $\bullet$ & $\bullet$ & $\bullet$ & $\bullet$ & $\bullet$ & $\bullet$ & $\bullet$ & $\bullet$ & $\bullet$ & $\bullet$ \\
\hline Great Britain & $\bullet$ & $\bullet$ & $\bullet$ & $\bullet$ & $\bullet$ & $\bullet$ & $\bullet$ & $\bullet$ & - & $\bullet$ & $\bullet$ & $\bullet$ & $\bullet$ & $\bullet$ & $\bullet$ & $\bullet$ & $\bullet$ & & & \\
\hline Greece & & & & & & & & $\bullet$ & & & & & & & & & & & & \\
\hline India & & & & & & & & & & & & & $\bullet$ & & & $\bullet$ & $\bullet$ & $\bullet$ & & \\
\hline Indonesia & & & & & & & & & & & & & & & $\bullet$ & $\bullet$ & & & & \\
\hline Italy & & $\bullet$ & $\bullet$ & & & $\bullet$ & & $\bullet$ & & & $\bullet$ & $\bullet$ & $\bullet$ & $\bullet$ & $\bullet$ & $\bullet$ & & & $\bullet$ & $\bullet$ \\
\hline Ireland & & $\bullet$ & $\bullet$ & & $\bullet$ & & & $\bullet$ & & & & & & & & & & & $\bullet$ & \\
\hline Malaysia & & & & $\bullet$ & $\bullet$ & - & & & & & & & & & & & & & $\bullet$ & \\
\hline Netherlands & $\bullet$ & & & & & $\bullet$ & $\bullet$ & $\bullet$ & $\bullet$ & $\bullet$ & & $\bullet$ & & & & & & & $\bullet$ & \\
\hline Norway & & & & & & & & & & & & $\bullet$ & $\bullet$ & & & & & $\bullet$ & & \\
\hline Pakistan & & & & & & & & $\bullet$ & $\bullet$ & & & & & & & $\bullet$ & $\bullet$ & & & - \\
\hline Romania & $\bullet$ & $\bullet$ & $\bullet$ & & & & & & $\bullet$ & & & & & & & $\bullet$ & & & $\bullet$ & $\bullet$ \\
\hline Saudi Arabia & & & & & & & & & $\bullet$ & $\bullet$ & $\bullet$ & $\bullet$ & $\bullet$ & $\bullet$ & & & $\bullet$ & & & \\
\hline Singapore & $\bullet$ & $\bullet$ & $\bullet$ & & & & & & & & & & & $\bullet$ & & & & & & \\
\hline South Africa & & & & & & & & & & & & & & & & $\bullet$ & $\bullet$ & $\bullet$ & & \\
\hline Spain & & $\bullet$ & & $\bullet$ & $\bullet$ & $\bullet$ & $\bullet$ & & & $\bullet$ & $\bullet$ & $\bullet$ & $\bullet$ & $\bullet$ & & & & $\bullet$ & & \\
\hline Sweden & & $\bullet$ & $\bullet$ & $\bullet$ & $\bullet$ & $\bullet$ & $\bullet$ & & & $\bullet$ & $\bullet$ & & & $\bullet$ & $\bullet$ & & $\bullet$ & $\bullet$ & $\bullet$ & $\bullet$ \\
\hline Thailand & & & & & & & & & & & & & & & & & & $\bullet$ & & \\
\hline UAE & & & & $\bullet$ & $\bullet$ & & & & & & & $\bullet$ & $\bullet$ & & $\bullet$ & & & & & \\
\hline USA & $\bullet$ & $\bullet$ & - & $\bullet$ & $\bullet$ & $\bullet$ & $\bullet$ & $\bullet$ & $\bullet$ & $\bullet$ & $\bullet$ & $\bullet$ & $\bullet$ & $\bullet$ & $\bullet$ & $\bullet$ & $\bullet$ & $\bullet$ & $\bullet$ & $\bullet$ \\
\hline
\end{tabular}


Annex 2

The Swiss arms exports by category throughout 2000-2019, percent (SIPRI, 2020b; The Wassenaar Arrangement, 2020)

\begin{tabular}{|c|c|c|c|c|c|c|c|c|c|c|c|c|c|c|c|c|c|c|c|c|}
\hline \multirow{2}{*}{$\begin{array}{c}\begin{array}{c}\text { Categories of dual-use goods, technologies and } \\
\text { munitions }\end{array} \\
\end{array}$} & \multicolumn{20}{|c|}{ Year } \\
\hline & 2000 & 2001 & 2002 & 2003 & 2004 & 2005 & 2006 & 2007 & 2008 & 2009 & 2010 & 2011 & 2012 & 2013 & 2014 & 2015 & 2016 & 2017 & 2018 & 2019 \\
\hline \begin{tabular}{|c|} 
Smooth-bore weapons with a calibre of less than 20 \\
mm, other arms with a calibre of $12.7 \mathrm{~mm}$ or less
\end{tabular} & 6.00 & 4.52 & 5.85 & 3.70 & 3.57 & 6.60 & 4.63 & 4.46 & 2.95 & 3.08 & 3.54 & 2.46 & 2.79 & 5.07 & 4.39 & 4.18 & 5.48 & 5.23 & 5.52 & 4.06 \\
\hline \begin{tabular}{|l|} 
Smooth-bore weapons with a calibre greater than 20 \\
mm, other arms with a calibre greater than $12.7 \mathrm{~mm}$
\end{tabular} & 24.00 & 17.25 & 16.23 & 9.95 & 6.34 & 9.38 & 11.43 & 18.06 & 19.75 & 13.34 & 17.68 & 8.95 & 12.28 & 15.02 & 24.44 & 14.89 & 16.67 & 7.96 & 10.12 & 8.40 \\
\hline Ammunition and fuse setting devices & 22.00 & 21.31 & 22.96 & 19.63 & 17.58 & 30.52 & 19.03 & 26.25 & 19.81 & 23.99 & 31.53 & 18.59 & 22.35 & 34.43 & 19.38 & 25.22 & 33.41 & 30.54 & 33.96 & 23.45 \\
\hline $\begin{array}{c}\text { Bombs, torpedoes, rockets, missiles, other explosive } \\
\text { devices }\end{array}$ & 2.00 & 3.77 & 5.88 & 4.90 & 2.15 & 0.43 & 0.73 & 0.07 & 1.89 & 2.24 & 1.21 & 0.43 & 1.32 & 2.38 & 0.31 & 0.10 & 0.40 & 0.57 & 4.46 & 1.08 \\
\hline $\begin{array}{c}\text { Fire control, and related alerting and warning } \\
\text { equipment }\end{array}$ & 17.00 & 15.32 & 15.96 & 20.62 & 16.89 & 15.12 & 5.80 & 10.32 & 11.25 & 16.02 & 13.93 & 12.30 & 14.56 & 16.10 & 19.60 & 30.42 & 27.93 & 39.43 & 6.85 & 11.61 \\
\hline Ground vehicles and components & 8.00 & 18.49 & 14.12 & 30.16 & 42.40 & 8.58 & 40.90 & 26.92 & 32.51 & 32.94 & 25.20 & 21.41 & 20.13 & 13.49 & 21.16 & 15.05 & 5.94 & 4.90 & 24.54 & 41.35 \\
\hline $\begin{array}{l}\text { Chemical, biological, riot control agents, } \\
\text { radioactive materials }\end{array}$ & 0.04 & 0.13 & 0.01 & 0.01 & 0.02 & 0.04 & 0.04 & 0.01 & 0.01 & 0.01 & 0.00 & 0.00 & 0.03 & 0.04 & 0.03 & 0.02 & 0.02 & 0.00 & 0.01 & 0.01 \\
\hline Energetic and related substances & 6.00 & 6.51 & 4.59 & 1.85 & 3.83 & 6.19 & 3.37 & 4.17 & 4.30 & 2.95 & 3.11 & 2.68 & 3.00 & 5.24 & 3.86 & 5.20 & 4.35 & 5.29 & 3.60 & 2.13 \\
\hline $\begin{array}{c}\text { Aircraft, unmanned aerial vehicles, aero engines } \\
\text { and equipment }\end{array}$ & 15.00 & 12.63 & 14.11 & 8.97 & 6.95 & 12.56 & 13.85 & 9.58 & 7.44 & 5.33 & 3.74 & 33.07 & 23.39 & 7.86 & 6.74 & 4.77 & 5.74 & 6.08 & 10.47 & 7.47 \\
\hline Forgings, castings and others unfinished products & - & 0.03 & 0.26 & 0.17 & 0.21 & 0.53 & 0.18 & 0.16 & 0.09 & 0.10 & 0.06 & 0.11 & 0.15 & 0.37 & 0.10 & 0.16 & 0.07 & 0.00 & 0.09 & 0.03 \\
\hline Directed energy weapon & - & - & - & - & - & - & - & - & - & - & - & - & - & - & - & - & - & - & - & 0.22 \\
\hline Cryogenic and superconductive equipment & 0.02 & - & - & - & - & - & - & - & - & - & - & - & - & - & - & - & - & - & - & - \\
\hline
\end{tabular}

